\title{
The Influence of Corporate Governance and Organizational Capacity on the Performance of Malaysian Listed Companies
}

\author{
Ifa Rizad Mustapa \\ Universiti Utara Malaysia \\ Email: ifarizad@yahoo.com \\ Nazli Anum Mohd. Ghazali \\ International Islamic University Malaysia \\ Email: nazlianum@iium.edu.my \\ Muslim Har Sani Mohamad \\ International Islamic University Malaysia \\ Email:muslimh@iium.edu.my
}

Doi:10.5901/mjss.2015.v6n3s1p27

\section{Abstract}

This study assesses the association between corporate governance and performance of companies listed on Bursa Malaysia. Although there is no clear evidence in the literature indicating that organizational capacity is influencing corporate performance, this study further examines the influence of corporate governance by combining it with organizational capacity. This study employs mail questionnaire in assessing the performance of companies. Using the data from the mail questionnaire, no significant relationship was found between independent director, CEO duality, board size, ownership concentration, financial management and corporate performance. Additionally, findings from the mail questionnaire showed that organizational learning was significant in explaining corporate performance. Two contributions are acknowledged in this research. First, the application of a mail questionnaire extends the research methodology on corporate performance and adds value in respect of how findings from the questionnaires highlight the perceptions of individuals pertaining to the research objectives. Second, using organizational capacity as an explanatory factor, this study documents that organizational learning emerges as an important aspect in influencing the performance of Malaysian companies.

Keywords: Corporate governance; organizational capacity; agency theory; resource-based view perspective, (RBV)

\section{Introduction}

The requirement to comply with the Malaysian Code on Corporate Governance (MCCG) recommendations among public listed companies has become very important in Malaysia since its introduction in 2000, which stresses on accountability and transparency. Companies that comply with the recommendation of the MCCG are expected to perform better than others. In respect of organizational capacity, which is understood as developing the resources and capabilities of an organization that are valuable, rare, imperfectly imitable and non-substitutable, this study is also interested in exploring the link between corporate governance and capabilities of a company. Although the link between corporate governance and corporate performance among Malaysian companies has long been researched, there is little empirical evidence concerning the assessment of the impact of organizational capacity on corporate performance. Accordingly, the aim of the current study was to establish the association between corporate governance practices and structures, as well as the elements of organizational capacity and the performance of Malaysian public listed companies. Various studies appeared to debate organizational capacity and the importance of resources to company performance (Barnet, 1986b, 1986c; O'Regan and Ghobadian, 2004; Bhatnagar, 2006; Adjaoud, Zeghal and Andaleeb, 2007). Hence, it is sufficient to test the association between these two variables and corporate performance to offer new findings in Malaysia. The first research objective is presumed to provide better investigation concerning the link between corporate governance and the performance of listed companies on Bursa Malaysia. Additionally, the second research objective is to identify the organizational capacity features in explaining corporate performance using the existing theoretical framework initiated 
from prior studies in developed countries.

\section{Literature Review}

With respect to this study, several theories were used in accordance with the multiple issues being investigated concerning corporate governance and organizational capacity and their impact on the performance of companies. The main theory being employed in the present study is the agency theory developed by Berle and Means (1932), which explains how to organize the relationship between the party that identifies the work and the party that takes the responsibility and apparently acts on behalf of the principal, known as the agent. In order to reduce the agency costs, to protect the shareholder interests and to ensure the alignment of the agent-principal interest, the agency theory prescribes a variety of corporate governance instruments. Based on the discussion with regard to the literature (Murray, 2003; Lopez, Peon and Ordas, 2005; Ho, 2008) underpinning the development of skill and the capability of a company is the resource-based view of the firm (RBV) perspective. According to the Resource-Based View (RBV) perspective, every organization employs a set of resources in creating its wealth by creating value in such a way that is exceptional and able to achieve competitive advantage. Examples of the resources are governing structure, financial monitoring, leadership, staffing, facilities, technology and human resources. Accordingly, very limited studies on organizational capacity in Malaysia have been identified (Tayles, Pike and Sofian, 2007; Khong and Eze, 2008; Fatt, Khin and Heng, 2010).

\subsection{Hypotheses Development}

\subsubsection{Corporate Governance Mechanisms}

Nonetheless, there are several studies in Malaysia (Abdullah, 2004; Leng, 2004; Rahim, Yaacob, Alias and Nor, 2010; Ponnu, 2008; Che Haat, Abdul Rahman and Mahenthiran, 2008; Mohd. Ghazali, 2010) that provide evidence that there is no statistical significant relationship between independent directors and company performance, indicating that board independence is not an important attribute in explaining company performance of Malaysian corporations. The findings also imply that independent directors do not influence company performance.

The Chief Executive Officer (CEO) and the Chairman are two separate individuals with different roles on the board. The analysis of results by Shakir (2009) on 81 property listed firms in Malaysia for the period 1999 to 2005 support the earlier findings by Donaldson and Davis (1991), and Coles, William \& Sen (2001), suggesting that a single leadership structure where the positions of a CEO and a Chairman are held by one individual will not lead to a decline in firm performance. A later finding by Abidin, Kamal and Jusoff (2009) show support to the prior results suggesting that role duality among Malaysian companies still has no influence on company performance.

As recommended by the Malaysian Code on Corporate Governance (MCCG) Revised 2007, every company should examine its board of director's size in order to determine the impact of the number upon the board's effectiveness. The KLSE/Price Waterhouse Coopers Joint Survey of Corporate Governance Practices in Public Listed Companies 1998 found that the average board size in Malaysian corporations was to be eight persons. On the other hand, the results of 73 companies listed on Bursa Malaysia show that board of directors in Malaysian companies perform more effectively in a larger group with more ideas and skills that can be shared among board members (Abidin et al., 2009).

Meanwhile, a published study by Chen, Cheung, Stouraitis and Wong (2005) evidenced that there is no statistical significant relationship between family ownership concentration and firm operating performance at any level of ownership and further identified that corporate governance mechanisms in Hong Kong firms appeared to be weak. In the case of Malaysia, Haniffa and Hudaib (2006) supports the findings of prior studies that illustrate that concentrated ownership produces better accounting results. The positive impact of ownership concentration on company performance implies that better performance of company is explained by ownership concentration. Thus, this finding is consistent with the theoretical expectation that concentrated ownership lowers agency costs. Based on the theories and mixed findings from prior studies, the following hypotheses have been developed:

$\mathrm{H}_{11 \text { ndDir }}$ : Independent director has no association with corporate performance.

$\mathrm{H}_{1 \text { Duality }}$ : CEO duality has no association with corporate performance.

$\mathrm{H}_{1 \mathrm{BrdSize}}$ : Board size has no association with corporate performance.

$\mathrm{H}_{10 w n c o n}$ : Ownership concentration has no association with corporate performance. 


\subsubsection{Organizational Capacity Element}

In terms of organizational capacity, Prieto and Revilla (2006) provides evidence that organizational learning could explain business performance. Two recent studies on financial training centres and technological companies in Taiwan (Lin and Kuo, 2007; Ho, 2008) support the finding by Prieto and Revilla (2006) that organizational learning (comprising several types - learning practices, information-sharing patterns, enquiry climate and achievement mindset) has a direct and positive significant influence on both financial and market performance. Thus, it is expected that organizational capacity can lead to better corporate performance.

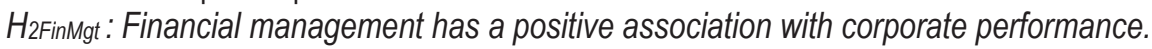

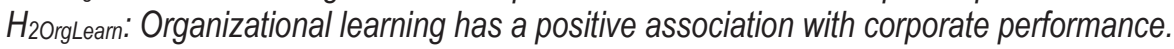

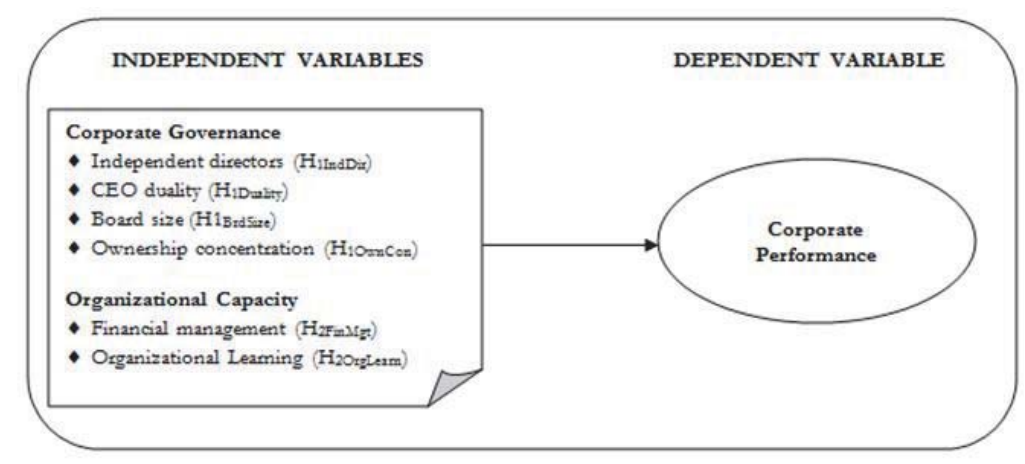

Figure 1. Theoretical Framework of Corporate Governance and Organizational Capacity and the Influence on Corporate Performance

\section{Research Methodology}

\subsection{Research Design}

The method employed in this study in analysing the data follows the methods widely used and applied in prior studies (Abdul Rashid et al., 2003; Abdullah, 2004; Haniffa and Hudaib, 2006; Amran and Che Ahmad, 2010). In examining the relationship between corporate governance as well as organizational capacity and performance of company, four corporate governance variables and two organizational capacity variables were measured in the current study. The measurement for the questionnaire data is presented in Table 1.

Table 1: Variable Measurement for Mail Questionnaire

\begin{tabular}{|c|c|c|c|}
\hline Variable & Acronym & Measured as & $\begin{array}{l}\text { Expected signs of } \\
\text { relationship }\end{array}$ \\
\hline \multicolumn{4}{|l|}{ Corporate Governance } \\
\hline CEO Duality & Duality & Score of 1 corporate governance item & - \\
\hline Board Size & BrdSize & Score of 1 corporate governance item & $+/-$ \\
\hline Ownership Concentration & OwnCon & Score of 1 corporate governance item & - \\
\hline \multicolumn{4}{|l|}{ Organizational Capacity } \\
\hline Financial Management & FinMgt & Total score of 8 organizational capacity items & + \\
\hline Organizational Learning & OrgLearn & Total score of 8 organizational capacity items & + \\
\hline Corporate Performance & \multicolumn{3}{|c|}{ Performance Total score of 10 company performance items } \\
\hline $\begin{array}{l}\text { Demographic characteristics of } \\
\text { respondents }\end{array}$ & \multicolumn{3}{|c|}{ Demographic Descriptive studies of respondents' profile } \\
\hline
\end{tabular}

\subsection{Data Collection and Estimation Approach}

The data was collected from a population of eight hundred (800) Malaysian listed companies. The targeted respondents 
were the Chief Financial Officer (CFO), Company Secretary or accountant of every company. The complete mail questionnaire survey was conducted from December 2009 to the end of April 2010.

The researcher adopted several items from two recent surveys in examining the influence of corporate governance mechanisms (i.e. independent director, CEO duality, board size, and ownership concentration) on the performance of companies. The two surveys are the "Corporate Governance Survey Report 2004", a joint study by the University of Nottingham and the Minority Shareholders Watchdog Group (MSWG) and the "Corporate Governance Screencard 2005", a joint study by the MSWG and the Universiti Teknologi MARA (UITM). Meanwhile, the questionnaire pertaining to organizational capacity elements, consist of financial management and organizational learning, was developed based on a research by the Inter-American Development Bank and the International Development Research Centre (IDRC), as compiled by Lusthaus, Andrien, Anderson, Carden and Montalvan (2002).

The respondents were asked to give their perception on their company's performance relative to their competitors using a seven-point interval scale for each item. The researcher runs the Mann-Whitney $U$ test to determine whether the early and late respondents have a significant difference in opinions. This study also conducted factor analysis to summarize the information contained in a number of original variables into a smaller set of new factors (Tabachnick and Fidell, 2001). The researcher also runs descriptive analysis together with multiple regression analysis in achieving objectives of the study. The Pearson Correlation was run to understand the interrelationships between the explanatory variables in the study. Model of the study is further presented as follow:

Performance $=a_{i}+\beta 1$ IndDir $+\beta 2$ Duality $+\beta 3$ BrdSize $+\beta 4$ OwnCon $+\beta 5$ FinMgt +

$\beta 6$ OrgLearn $+\epsilon$

(Equation 1.0)

\section{Results}

With respect to the estimation approach, the descriptive analysis as well as the multiple regression analysis has been employed in regressing the mail questionnaire data. Based on the Mann-Whitney $U$ test, the result shows that there were no significant differences (Sig. two-tailed >.05) in response to the questionnaire between the five early and late respondents for all variables. After conducting the factor analysis, the organizational capacity elements and corporate performance variables have been factorised into three variables. The reliability test was conducted and all constructs have a Cronbach's alpha value well above 0.7 , which indicates more than acceptable.

Meanwhile, the results of Kaiser-Meyer-Olkin Measure of Sampling Adequacy (KMO) for organizational capacity and corporate performance constructs were above the acceptance value which testifies that organizational capacity and corporate performance were constructively valid. The Pearson Product-Moment Correlation shows that none of the independent variables seems highly correlated with each other as correlation coefficients are below 0.7 (Hair, Black, Babin and Anderson, 2010). Table 2 illustrates the descriptive results of all companies as a whole.

Table 2: Descriptive Statistics for Corporate Governance, Organizational Capacity and Corporate Performance

\begin{tabular}{|c|c|c|c|c|c|}
\hline Independent Variables & Mean & Median & Max & Min & Std. Deviation \\
\hline \multicolumn{6}{|l|}{ Corporate Governance Mechanisms } \\
\hline Independent Director (IndDir) & 5.4835 & 6 & 7 & 3 & 1.2593 \\
\hline CEO Duality (Duality) & 5.5714 & 6 & 7 & 1 & 1.3345 \\
\hline Board Size (BrdSize) & 5.2198 & 5 & 7 & 1 & 1.3400 \\
\hline Ownership Concentration (OwnCon) & 4.4835 & 4 & 7 & 1 & 1.6355 \\
\hline $\begin{array}{l}\text { Organizational Capacity Elements } \\
\text { Financial Management(FinMat) }\end{array}$ & 5.5124 & 5.6250 & 7 & 3.38 & 0.9134 \\
\hline Organizational Learning (OrgLearn) & 5.0687 & 5.2500 & 6.88 & 2.63 & 0.9452 \\
\hline $\begin{array}{l}\text { Corporate Performance Characteris } \\
\text { Corporate Performance }\end{array}$ & 4.6154 & 4.7000 & 6.40 & 1.70 & 0.9950 \\
\hline
\end{tabular}

Results of the regression on the effect of corporate governance and organizational capacity on corporate performance for all companies are demonstrated in Table 3. In the model of regression, the findings implies that approximately 29.5 per cent (Adjusted $R^{2}=0.295, p<0.01$ ) of the total variance of corporate performance is explained by corporate governance mechanisms and organizational capacity elements in the model as a whole.

Analysis on the regression result in Table 3 shows that only one variable was found to be significant which is 
organizational learning (OrgLearn) $(\beta=0.535, p<0.01)$. On the other hand, all the other five independent variables comprising independent director (IndDir) ( $\beta=-0.187, p=0.138$ ), CEO duality (Duality) $(\beta=0.113, p=0.290$ ), board size (BrdSize) $(\beta=0.079, p=0.490)$, ownership concentration (OwnCon) $(\beta=-0.053, p=0.635)$ and financial management (FinMgt) $(\beta=0.073, p=0.559)$ were determined as not associated with performance of company.

Table 3: Results of Multiple Regression Analyses of Corporate Governance and Organizational Capacity on Corporate Performance

\begin{tabular}{|c|c|c|c|}
\hline Predictor & Standardized Coefficient Beta $(\beta)$ & t statistics & Significance value (p) \\
\hline (Constant) & & 2.382 & 0.019 \\
\hline Independent director & -0.187 & -1.498 & 0.138 \\
\hline CEO duality & 0.113 & 1.064 & 0.290 \\
\hline Board size & 0.079 & 0.693 & 0.490 \\
\hline Ownership concentration & -0.053 & -0.476 & 0.635 \\
\hline Financial management & 0.073 & 0.587 & 0.559 \\
\hline Organizational learning & $0.535^{\star * *}$ & 4.170 & 0.000 \\
\hline $\mathrm{R}^{2}$ & & 0.342 & \\
\hline Adjusted $\mathrm{R}^{2}$ & & 0.295 & \\
\hline F Change & & 7.285 & \\
\hline Significance & & 0.000 & \\
\hline Durbin-Watson Index & & 2.038 & \\
\hline
\end{tabular}

Note: ${ }^{* \star} p<0.01,{ }^{\star \star} p<0.05,{ }^{*} p<0.10$

Consistent with the findings by Amran and Ahmad (2010) and Rahim et al., (2010), the result with regard to proportion of board independence on board implies that companies do not fully utilize the functions of independent directors. Therefore, the finding is not aligned with the agent-principal perspective. Apart from that, the finding also does not support the stewardship theory suggesting that board of directors prefers having more executives or inside directors than independent directors. According to the stewardship theory, there exists a strong relationship between executives' pursuit of the objective of the company, the satisfaction of the owners and the stakeholders in the company. The insignificant result implied that independent directors on board of directors do not have an influence on corporate performance.

With respect to CEO duality (duality), the result shows no significant relationship with corporate performance. Hence, the finding does not support the agency theory prediction which argues that the Chairman is responsible to administer the company's management while the CEO is responsible to manage the company through protecting the shareholders' shares. Moreover, the result in this study is also not consistent with the recommendation made by the MCCG 2001, that the role of the CEO and the Chairman should be separated. The association between CEO duality and company performance is also not aligned with the stewardship theoretical framework that proposes combination of the roles of the CEO and Chairman will improve company performance through a smoothing progress of decision making process while maximizing shareholder's wealth. It is interesting to note that perhaps employees in Malaysian companies these days cannot accept that having a CEO who is believed to be capable of being a leader with multitasking positions duality is an essential factor to a better performance.

Finding in the current study also shows that board size is not related to performance of a company. The finding does not support the findings by Yermack (1996), Rahim et al. (2010) and Ibrahim \& Samad (2011) which documented that smaller board with less number of people on board could bring greater performance to companies. As group increase in size, they become less effective because less coordination among the people involved somehow devastates the decision making process.

Further finding in this study indicates that ownership concentration (OwnCon) measured as the percentages of top ten largest shareholding is evidenced to have no impact on company performance. The finding is inconsistent with the finding by Haniffa and Hudaib (2006) reporting that concentrated ownership produces better accounting results. However, the result supports studies by Franks and Mayer (2001), Leng (2004) and Chen et al. (2005) suggesting that largest shareholders do not influence company performance through business strategies.

With regard to organizational capacity, the resource-based-view (RBV) perspective provides a notion that firms must obtain sources of competitive advantage and may use these resources to create and implement valuable strategies. Firm resources are described as assets, capabilities, organizational processes, organizational attributes, knowledge, information, technologies, etc., controlled by a firm (Barney, 1991). The result of the empirical test reports that financial management was not statistically significant in explaining performance of companies. For instance, plan and sufficient 
budget of companies and auditing did not assist in generating value to companies.

On the other hand, the finding pertaining to organizational learning was found to be consistent with the proposed RBV perspective which shows that performance of company was significant and positively influenced by this organizational capacity element. This finding supports prior studies by Murray (2003), Lopez et al. (2005) and Ho (2008).

Therefore, the positive and significant finding with regard to organizational learning implies that employees are capable of making decision concerning their job. Consequently, individuals are given the opportunity to learn new knowledge and skills, and at the same time, gain experience during their employment period. The positive significant impact of organizational capacity of company also suggests that a company has to further develop and transform simultaneously through higher learning.

Particularly, this study finds that independent director (IndDir), CEO duality (Duality), board size (BrdSize), ownership concentration (OwnCon) and financial management (FinMgt) were not significant in explaining performance of Malaysian listed companies. However, organizational learning (OrgLearn) was statistically significant which provide evidence on the association between organizational learning and corporate performance. Therefore, findings in the current study fail to reject $\mathrm{H}_{11 \text { ndDir, }} \mathrm{H}_{1}$ Duality, $\mathrm{H}_{1 \text { BrdSize, }} \mathrm{H}_{1}$ Owncon and $\mathrm{H}_{2}$ OrgLearn but rejects $\mathrm{H}_{2}$ FinMgt.

\section{Concluding Remarks}

In conclusion, even though the requirement of the implementation of good corporate governance is essential to companies in Malaysia, but findings in this study evidenced that not all aspects of corporate governance has significant effect on corporate performance. In addition, this study further finds a positive statistical significant association between organizational capacity element, organizational learning (OrgLearn) and corporate performance. The finding contributes towards highlighting the importance of companies to create competitive advantage resources towards enhancing longterm performance.

\section{References}

Abdul Rashid, Md. Z., Sambasivan, M. and Johari, J. (2003). The influence of corporate culture and organizational commitment on performance, Journal of Management Development, 22 (8), 708-728.

Abdullah, S.N. (2004). Board composition, CEO duality and performance among Malaysian listed companies. Journal of Corporate Governance, 4 (4), 47-61.

Abidin, Z.Z., Kamal, N.M. and Jusoff, K. (2009). Board Structure and Corporate Performance in Malaysia. International Journal of Economics and Finance, 1 (1), 150-164.

Adjaoud, F., Zeghal, D. and Andaleeb, S. (2007). The effect of board's quality on performance: A study of Canadian firms. Corporate Governance, 15 (4), 623-635.

Amran, N.A \& Che Ahmad, A. (2010). Corporate Governance Mechanisms and Performance: Analysis of Malaysian Family and NonFamily Controlled Companies. Journal of Modern Accounting and Auditing, 6 (2), 1-15.

Barney, J.B. (1991). Firm Resources and Sustained Competitive Advantage. Journal of Management, 17 (1), 99-120.

Berle, A.A. \& Means, G.C. (2002). The Modern Corporation \& Private Property: With a new introduction by Murray Weidenbaum and Mark Jensen. New Jersey: Transaction Publishers.

Bhatnagar, J. (2006). Measuring organizational learning capability in Indian managers and establishing firm performance linkage. The Learning Organization, 12 (5), 416-433.

Che Haat, M.H., Abdul Rahman, R. \& Mahenthiran, S. (2008). Corporate Governance, transparency and performance of Malaysian companies. Managerial Auditing Journal, 23 (8), 744-778.

Chen, Z., Cheung, Y., Stouraitis, A. \& Wong, A.W.S. (2005). Ownership concentration, firm performance, and dividend policy in Hong Kong. Pacific-Basin Finance Journal, 13, 431-449.

Donaldson, L. \& Davis, J.H. (1991). Stewardship Theory or Agency Theory. Australian Journal of Management, 16 (1), 49-65.

Fatt,C.K., Khin, E.W.S. \& Heng, T.N. (2010). The Impact of International Justice on Employee's Job Satisfaction: The Malaysian Companies Perspectives. American Journal of Economics and Business Administration, 2 (1), 56-63.

Hair, J.F., Black, W.C, Babin, B.J. \& Anderson, R.E. (2010). Multivariate Data Analysis: A Global Perspective (7 ${ }^{\text {th }}$ edn.). New Jersey: Prentice Hall.

Haniffa, R.M. \& Hudaib, M. (2006). Corporate governance structure and performance of Malaysian listed firms. Journal of Business Finance \& Accounting, 33 (7) \& (8),1034-1062.

Ho, L. (2008). What Affects Organizational Performance? The Linking of Learning and Knowledge Management. Industrial Management and Data Systems, 108 (9), 1234-1254.

Hofstede, G. (1998). Attitudes, Values and Organizational Culture: Disentangling the Concepts. Organization Studies, 19 (3), $477-492$.

Ibrahim, H. \& Samad, F.A. (2011). Corporate Governance Mechanisms and Performance of Public-Listed Family-Ownership in Malaysia. International Journal of Economics and Finance, 3 (1), 105-115. 
Khong, S.T. \& Eze, U.C. (2008). An Empirical Study of Internet-Based ICT Adoption Among Malaysian SMEs. Communications of the IBIMA, 1, 1-12.

Leng, A.C.A. (2004). The Impact of Corporate Governance Practices on Firms' Financial Performance. ASEAN Economic Bulletin, 21 (3), 308-318.

Lin, C. \& Kuo, T. (2007). The Mediate Effect of Learning and Knowledge on Organizational Performance. Industrial Management and Data Systems, 107 (7), 1066-1083.

Lopez, S.P., Peon, J.M.M. and Ordas, C.J.V. (2005). Organizational Learning as Determining Factor in Business Performance. The Learning Organization, 12 (3), 227-245.

Lusthaus, C., Andrien, M., Anderson, G., Carden, F.\& Montalvan, G.P. (2002). Organization Assessment: A Framework for Improving Performance. Canada \& Washington: International Development Research Centre and Inter-American Development Bank.

Malaysian Code on Corporate Governance. (2001). Finance Committee on Corporate Governance. Kuala Lumpur: Malayan Law Journal Sdn Bhd.

Mohd. Ghazali, N.A. (2010). Ownership structure, corporate governance and corporate performance in Malaysia. International Journal of Commerce and Management, 20 (2), 109-119.

Murray, P. (2003). Organizational Learning, Competencies and Firm Performance: Empirical Observations. The Learning Organization, Vol. 10, No. 5, pp. 305-316.Ponnu, C.H. (2008). Corporate Governance Structures and the Performance of Malaysian Public Listed Companies. International Review of Business Research Papers, 4 (2), 217-230.

O'Regan, N. and Ghobadian, A. (2004). The importance of capabilities for strategic direction and performance. Management Decision, $42(2), 292-312$.

Prieto, I.M. \& Revilla, E. (2006). Learning Capability and Business Performance: A Non-Financial Assessment. The Learning Organization, 13 (2), 166-185.

Rahim, R.A., Yaacob, M.H., Alias, N. \& Nor, F.M. (2010). Investment, Board Governance and Firm Value: A Panel Data Analysis. International Review of Business Research Papers, 6 (5), 293-302.

Shakir, R. (2009). Examining the Effect of Leadership Structure and CEO Tenure on Malaysian Property Firm Performance. Journal of Real Estate Literature, 17 (1), 47-62.

Tabachnick, B.G. \& Fidell, L.S. (2001). Using Multivariate Statistics (4th edn.). New York: HarperCollins.

Tayles, M., Pike, R.H. \& Sofian, S. (2007). Intellectual Capital, Management Accounting Practices and Corporate Performance: Perception of Managers. Accounting, Auditing and Accountability Journal, 20 (4), 522-548.

Yermack, D. (1996). Higher Market Valuation for Firms with Small Board of Directors. Journal of Corporate Finance, 40, $185-211$. 